University of Chicago Law School

Chicago Unbound

\title{
Becker on Ewald on Foucault on Becker American Neoliberalism and Michel Foucault's 1979 'Birth of Biopolitics' Lectures
}

\author{
Gary S. Becker \\ François Ewald \\ Bernard E. Harcourt
}

Follow this and additional works at: https://chicagounbound.uchicago.edu/public_law_and_legal_theory

Part of the Law Commons

Chicago Unbound includes both works in progress and final versions of articles. Please be aware that a more recent version of this article may be available on Chicago Unbound, SSRN or elsewhere.

\section{Recommended Citation}

Gary S. Becker, François Ewald \& Bernard E. Harcourt, "Becker on Ewald on Foucault on Becker American Neoliberalism and Michel Foucault's 1979 'Birth of Biopolitics' Lectures" (University of Chicago Public Law \& Legal Theory Working Paper No. 401, 2012).

This Working Paper is brought to you for free and open access by the Working Papers at Chicago Unbound. It has been accepted for inclusion in Public Law and Legal Theory Working Papers by an authorized administrator of Chicago Unbound. For more information, please contact unbound@law.uchicago.edu. 


\section{CHICAGO}

Public laW and Legal Theory Working Paper No. 401

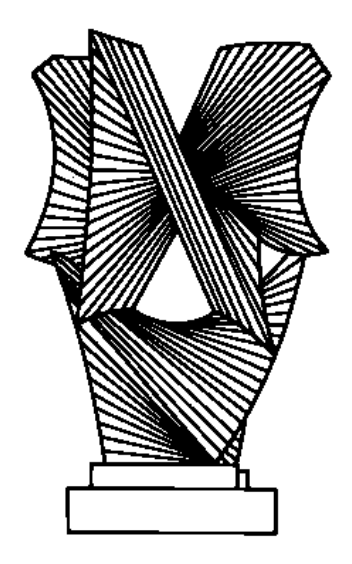

\section{"BECKER ON EWALD ON FOUCAULT ON BECKER" AMERICAN NEOLIBERALISM AND MICHEL FOUCAULT'S 1979 BIRTH OF BIOPOLITICS LECTURES}

A conversation with Gary Becker, François Ewald, and Bernard Harcourt

THE LAW SCHOOL THE UNIVERSITY OF CHICAGO

September 2012

This paper can be downloaded without charge at the Public Law and Legal Theory Working Paper Series: http://www.law.uchicago.edu/academics/publiclaw/index.html and The Social Science Research Network Electronic Paper Collection. 


\title{
"Becker on Ewald on Foucault on Becker"
}

\section{American Neoliberalism and Michel Foucault's 1979 Birth of Biopolitics Lectures:}

\section{A Conversation with Gary Becker, François Ewald, and Bernard Harcourt}

\author{
The University of Chicago - May 9, 2012 ${ }^{1}$
}

Bernard Harcourt: Welcome everyone. I was just reading in the news that a number of universitiesHarvard, MIT, Princeton, and Stanford-have begun free on-line courses, open to everyone. So I think this is our first contribution to that effort, because we are an open seminar today, ungrounded in some sense-although the Political Theory Workshop has been generous enough to host us-open to everyone and obviously packed. So this is a good sign.

On behalf of the University of Chicago, welcome Professor François Ewald and Professor Gary Becker to discuss Foucault's lectures on American neoliberalism. This open seminar is fortuitous. Professor François Ewald was invited to the University of Chicago by the Chicago Center for Contemporary Theory (3CT) for a conference on "The Future of Risk," along with Professors Patrick O'Malley from the University of Sydney and Caitlin Zaloom from New York University. (There are some brochures about the conference which is on Friday at the International-House, and I encourage you to join us. It should be fascinating). As you all know well, François Ewald holds the chair in insurance studies at the Conservatoire National des Arts et Métiers and is the director of the École nationale d'assurances. ${ }^{2}$ Professor Ewald was also, importantly, Michel Foucault's principle assistant and interlocutor at the Collège de France from 1976 to 1984 and the founder of the Michel Foucault Center, and has been responsible for the publication of Foucault's work with Daniel Defert.

When I realized that Professor Ewald would be at the University of Chicago with us, I immediately wrote to Professor Gary Becker, our most illustrious and accomplished professor in

\footnotetext{
${ }^{1}$ This is an edited transcript of a conversation held at The University of Chicago on May 9, 2012, in Foster Hall 505, the seminar room of the Committee on Social Thought. The video recording of the open seminar can be viewed on-line at http://vimeo.com/43984248. Professors Gary Becker and François Ewald have individually reviewed and edited their portions of the conversation; Professor Bernard Harcourt has edited and annotated the text. We are extremely grateful to Anwen Tormey and the Chicago Center for Contemporary Theory (3CT) for inviting Professor Ewald to the University of Chicago, and to Gary Becker for participating in this conversation.

${ }^{2}$ Professor François Ewald's publications include, in English: François Ewald, "The Return of Descartes's Malicious Demon: An Outline of a Philosophy of Precaution," in Tom Baker and Jonathan Simon, eds., Embracing Risk (University of Chicago Press 2002); and François Ewald, "Insurance and Risk," in Graham Burchell, Colin Gordon \& Peter Miller, eds, The Foucault Effect: Studies in Governmentality (University of Chicago Press 1991); and in French: François Ewald, L'État providence (Grasset 1986); and François Ewald, Christian Gollier, and Nicolas de Sadeleer, Le principe de précaution (PUF 2001).
} 
economics and sociology and a recipient of the Nobel Prize, ${ }^{3}$ and asked him whether he would be interested in discussing Foucault's writings on ... Gary Becker.

As you know, in a series of important lectures delivered in 1979 under the title The Birth of Biopolitics, Michel Foucault engaged Gary Becker's work within the context of an elaboration and critique of different kinds of neoliberalism. And he was, specifically in those three lectures-lectures nine, ten, and eleven ${ }^{4}$-looking at American neoliberalism, as opposed to German ordo-liberalism and French neoliberalism. Professor Becker immediately responded that he would be happy to read Foucault's lectures and come to discuss Foucault's work-and here I should just interject that I think this is precisely what makes the University of Chicago so remarkable: this willingness to read and engage critical work-which reflects how deeply we value the life of the mind and ideas here in Chicago. And I'll say it's precisely why I dedicated my last book, which was a critique of the Chicago School of Economics, to Gary Becker ${ }^{5}$. Precisely for being such an extraordinary and open colleague-open to ideas, exchange, and critique.

As a teaser for this seminar I will tell you that in a glorious e-mail that Professor Becker sent to me the day before yesterday, Gary Becker wrote (referring to Michel Foucault's work), "I like most of it, and I do not agree with much...

Gary Becker: I don't disagree with much...

Bernard Harcourt: "I don't disagree with much." Did I just say that? Is that Freudian perhaps? I will slow down and repeat that! "I like most of it, and I do not disagree with much. I also cannot tell whether Foucault is disagreeing with me." That truly sets the tone for this historic conversation.

So I will ask François Ewald to start with the historical and intellectual context of Foucault's lectures, before turning it over to Gary Becker for his reactions. I may intervene. I will ask Chris Berk, a brilliant doctoral student in political theory, also to intervene, before we open up the seminar to discussion. Of course, we're in Chicago, so, as you know, some people don't always wait before intervening. One final remark, several colleagues couldn't be here and asked that I record this open seminar, and so I will be doing that through various mechanisms that may or may not work, I'm not sure. But let's get started.

\footnotetext{
${ }^{3}$ Professor Gary Becker's publications include: Gary S. Becker, Human Capital: A Theoretical and Empirical Analysis, with Special Reference to Education (University of Chicago Press 1964); The Economics of Discrimination (University of Chicago Press 1971); A Treatise on the Family (Harvard University Press 1991); and Accounting for Tastes (Harvard University Press 1996).

${ }^{4}$ Michel Foucault, The Birth of Biopolitics: Lectures at the Collège de France, 1978-79, English series ed. Arnold I. Davidson, trans. Graham Burchell (Palgrave Macmillan 2008), pp. 215-289.

${ }^{5}$ Bernard E. Harcourt, The Illusion of Free Markets: Punishment and the Myth of Natural Order (Harvard University Press 2011).
} 
François Ewald: Thank you, Bernard, for this invitation. Maybe this presentation will be very hard for you because my English is so bad. That is a pity, such bad English with so great a professor [Becker]...

Gary Becker: ... your English is a lot better than my French.

François Ewald: So, I will try to do my job, that is, to remember the context. In my view, that is not the same thing as saying what Foucault would say if he were here. So, I will give you my view. I will try to explain this paradox: How was it possible that an intellectual, a French philosopher-someone perhaps known as a Left French philosopher, a radical-would deliver, at the end of the 1970s, a lecture at the Collège de France where he would make the apology of neoliberalism-especially the apology of Gary Becker, who is referred to in the book, The Birth of Biopolitics, as the most radical representative of American neoliberalism?

What is interesting to understand is how it was possible that such a French philosopher would enlist Gary Becker in a story that is, in fact, a story about truth. Because the relationship between Foucault and Gary Becker is a relationship in respect of truth-telling, and that is what is most interesting. From this perspective, I think, we don't need to believe that the interest for Foucault was about liberalism. I think he was interested in liberalism not as an ideology. He was very interested in liberalism-not as an ideology, not as a philosophy-but because liberalism was for him an epistemology. And the reason, I think, Foucault was interested in your work was because he was interested in your manner of thinking, not in your convictions. Maybe that is the reason that Foucault never sought out to meet you. It is not your person, but your way of thinking that was important to him.

So I will explain my sense of the context with four remarks. The first one concerns the French historical context at the time Foucault delivered these lectures. We were, in France, still in the aftermath of May '68, and that was a time of liberation. The big question was how it would be possible to think outside of the old framework of thinking in France. We were searching for how to liberate ourselves from the past. And that is the reason that it was possible to be interested by such questions as liberalism or economics or American economy, and so on. But that is merely the immediate historical context.

In fact, as you may know, Foucault faced a particular challenge in France, which was to give the true interpretation of the events of '68. In 1972, Gilles Deleuze and Félix Guattari gave a whole interpretation with a theory of desire ${ }^{6}$; and Foucault's response would come later, in 1975, with the publication of Discipline and Punish. ${ }^{7}$ Foucault's interpretation focused on the question of power, but in the agenda of May '68. It was a question of power and of power relationships. And the peoplepoliticians, historians, philosophers-in France asked him two questions: yes, they said, but with your theory of micro-power it would be impossible for you to give a theory of the state.

\footnotetext{
${ }^{6}$ Gilles Deleuze and Félix Guattari, Anti-Oedipus: Capitalism and Schizophrenia, trans. Robert Hurley, Mark Seem, and Helen R. Lane (University of Minnesota Press 1983 [1972]). Foucault wrote an important preface to the English edition.

7 Michel Foucault, Discipline and Punish: The Birth of the Prison, trans. Alan Sheridan (Pantheon Books 1978 [1975]).
} 
In these lectures [on American neoliberalism], you have Foucault's response to this question. And Foucault's response is: "We don't need a theory of the state, we need a theory of government." The state is not at the core of the political question. What is at the core of the political question is a question of government, of governmentality. And Foucault searched for and proposed a theory of governmentality during these two years of lectures at the College de France ${ }^{8}$. And the second year was dedicated to modern governmentality - that is, a governmentality where the truth-telling of the government is given by economics. And that is the definition for Foucault of liberalism.

So, that is the game, Foucault's game. A very hard question in France, in the French context, about a theory of the state, and the response from Foucault is: The state is not the question, the question is governmentality.

Second point: if you read this lecture, you can see that Foucault proposes a theory of liberalism, but he does so without a single quotation from a philosophical thinker of liberalism. The sole thinkers of liberalism, in Foucault's account, are economists. I suspect, for you, that this is strange-this identification between economists and liberalism. But the sole liberalism for Foucault, the sole interesting liberalism is the liberalism practiced by economists and not by the theoreticians of the political or of the philosophical politics of liberalism. Why? Because Foucault gives to the economists a very specific status, that is, they are truth producers. I am not sure that my accent is good. Please, Bernard, help me. La verité...

Bernard Harcourt: Truth producers. Producers of veridiction. ${ }^{9}$

François Ewald: That is very important in Foucault's game, because you can see in the text that what Foucault is searching for is a theory, a non-moral theory, and a non-juridical theory. The challenge is to be free from morality and from the law. And he finds, I think, the solution in the writings of the economists. That is a celebration of the economists' work, of your work. You propose a theory of man, a vision of man, that is non-moral and non-juridical. And that is, for him at this time, in this project naturally, very important.

Gary Becker for Foucault is a moment in the very long story of truth-telling-of a truth-telling free from a moral and juridical framework.

Third point. There is a text, an early text of Foucault, where he says that in the twentieth century the philosophical acts are not in philosophy, but in other fields. For example, a very important philosophical act in the twentieth century was Freud's doctrine of psychoanalysis; or the theory of linguistics by Saussure. I think that Foucault, when he read your work, believed that economics-and

\footnotetext{
${ }^{8}$ The prior year's lectures are published under the title Security, Territory, Population: Lectures at the Collège de France, 1977-1978, English series ed. Arnold I. Davidson, trans. Graham Burchell (Palgrave Macmillan 2007).

${ }^{9}$ The term "veridiction" is Foucault's. It is a neologism made up of the Latin root veri for truth, and diction for speaking, pronouncing, or telling. It captures best this notion of truth-telling. See generally Michel Foucault, Wrong-Doing, Truth-Telling: The Function of Avowal in Justice, eds. Fabienne Brion and Bernard E. Harcourt, trans. Stephen W. Sawyer (University of Chicago Press 2013).
} 
your kind of economics-was for our time a philosophical act. That it is a field, a place where we can observe a philosophical act. Philosophical acts are very important for Foucault because we are dependent on philosophical acts. And the object of Foucault's philosophy is to identify such kinds of acts, to be free from such kinds of acts, in order to create the possibility for other acts in the future.

What was, in his perspective, your act? It is to transform economics. And to make economics not only a theory, not only an observation or an analysis of wealth, but to make the shift from wealth to human behavior - the shift from wealth to value-and to make economics a science of evaluation. How do people make evaluations? That is a question of value. Naturally, value is close to wealth, but value is more complex. And your change of the field of economics is, in a sense, parallel to the change that Foucault operated within philosophy with regard to the study of power. There is a parallel in the shift from macroeconomics to microeconomics. I think that a consequence of this act for Foucault-and that is the reason that I can speak of an "apology" - has to do with liberty, which is why the question of truth is so important to Foucault: because our liberty, the possibility of liberty, depends on the manner that we tell truth, or produce truth. Certain kinds of truth-telling are death for liberty, other kinds of truthtelling give new possibilities for liberty. And he sees your work, your kind of analyses as creating the possibility to promote, to envision new kinds of liberty.

For example-Bernard is very interested by this-your work offers the possibility of thinking about power without discipline. Because of the way you think, your theory of regulation makes it possible to conduct the behavior of the other without coercion, by incitation. Another aspect, very important, where you are very close to Foucault, has to do with the passage where Foucault uses your work about the enforcement of law. What is very interesting for him in this respect is to conduct an analysis of law, in respect of the enforcement of law, that implies that there are only power relationships. And the relation between the agent and the power is only a fight-a calculus-absolutely free of moral questions or juridical questions. And that was, I think, for him, something very, very interesting.

So, next point. I suggested at the beginning of my talk the idea of an "apology" by Foucault of Gary Becker. Naturally, the question this raises is: Had Foucault become a pupil of Gary Becker? I don't know. [Laughter]. But we can make several observations.

The first one is that Foucault found your proposition-your practical proposition, for example, regarding crime and punishment and so on-I think, very intelligent and very malicious, with respect to what were the commonly-held ideas at the time. That was his first interest.

Second, though this one is not in this particular lecture, but before it. In the text, Foucault tells us about the theory of fiction. I think that is very important because, for Foucault, the man you produce by the economic analysis is not real. He is a fiction. This fiction is interesting. This fiction created new possibilities. This kind of fiction could be dangerous, but it could also be interesting. But it is a fiction.

And that is the reason that Foucault is not your pupil, because he is very interested in how your kind of economics produces a new vision of man, in a very interesting context in relationship with 
government, with power. But it is forbidden to think that this kind of man is real. He is produced in a power relationship where-and this is the difference with an ideological perspective, that is, your work is linked to the truth. That is what makes [your work so interesting for Foucault].

From another perspective, we can observe that your work on how economists conceive of human agents was very close to what Foucault searched for with his theory of the subject and of subjectivity. That is very interesting for me-that is, Foucault could read in your work how the agent, in the economy, is always deciding, making decisions. And for Foucault, with his theory of power, it was very difficult to think how the subject decides: he is decided by power relations. But Foucault could find in your work a solution and maybe we can see the reading of your work by Foucault like a step between his earlier theory of power ${ }^{10}$ and the later Foucault lectures about subjectivity and so on ${ }^{11}$.

So, naturally we can regret the meeting in '79 or maybe the early ' 80 s between Gary Becker and Foucault on the University of Chicago campus. Maybe. Perhaps because we can imagine that the conversation between Foucault's vision of power relationships and the vision of the decision in your theory could have been very fruitful. But why was this meeting not possible? Because even though at the University of Chicago there may have been a possible connection between the French philosopher and the economist, there may have been a difficulty with the Department of Political Science at that time, where the question of liberalism was not viewed in the same manner. And there were French scholars here in this Department of Political Science at the time, but they were very hard against Foucault. And that is also the reason why, I think maybe, thanks to Bernard, the possibility of this meeting is such a very big pleasure for me, but also perhaps a little mark in the history of this University.

Bernard Harcourt: Thank you. Fascinating. Now, I would want to add a fifth and a sixth point that sharpen, I think, the critique and maybe turn it from an apology to a critique. But, I don't think I should do that just yet. I think that you-

Gary Becker: I would like to hear. I'll respond afterwards.

Bernard Harcourt: Really?

Gary Becker: Yes. Sure, definitely.

Bernard Harcourt: Okay. Alright. So you'll have to respond to two different takes, right?

Gary Becker: I'll try. I'll try.

Bernard Harcourt: Okay. By way of background, I think it's important to say that, obviously, Foucault never turned these lectures into a written text and that's very important. Daniel Defert, Foucault's

\footnotetext{
${ }^{10}$ See generally Discipline and Punish (1975) and History of Sexuality, Volume I (1976), as well as Foucault's earlier lectures at the Collège de France, especially La société punitive (1972-73), Psychiatric Power (1973-74), and "Society Must Be Defended" (1975-76).

${ }^{11}$ See generally Foucault's later lectures at the Collège de France from Hermeneutics of the Subject (1981-82) through The Courage of Truth (1984), as well as the Louvain lectures, Wrong-Doing, Truth-Telling (1981).
} 
partner, is fond of recounting how Foucault wrote his books. And he wrote them, according to Daniel, three times. The first manuscript he would throw out and say that he'd written everything he did not want to say. The second, he would have typed up and he would use as the basis for the third manuscript, which was the book. So as a historical matter, it's possible that these lectures represent the first draft: What he did not feel that he needed to say or necessarily wanted to say.

So that should put us, I think, in a bit of a cautious interpretive position to begin with. But, naturally, Foucault does say specific things about American neoliberalism, and they've been somewhat controversial. Some scholars, like the intellectual historian Michael Behrent, have gone so far as to suggest Foucault had a general penchant, a general favor for neoliberalism. ${ }^{12}$ And that, of course, is implied in the question at the beginning of François Ewald's fourth point-namely whether Foucault was a pupil of Gary Becker. I think that goes too far, though it is sometimes difficult to focus specifically on the exact nature of the critique. So what l'd like to do is just that: to try and identify where the critique might be. I think François Ewald has articulated and offered something that will overlap significantly and that may actually underlie part of what I'm going to say-maybe the most important critique-and it's this notion of seeing power without coercion. And so I will come back to that.

Others have identified other critiques which I do not believe are entirely correct. Colin Gordon, in an early chapter of The Foucault Effect, focuses on the notion of the malleability of the neoliberal subject; and this notion of the malleability, the shape-ability, of the neoliberal subject is something that, I think, he views as cautiously problematic. He writes, "the American neo-liberal homo economicus is manipulable man, man who is perpetually responsive to modifications in his environment. Economic government here joins hands with behaviorism."13 So [you can see here] this notion that the idea of human capital or the notion of homo economicus would feed into behaviorism and that that is particularly problematic.

Now, Foucault refers to this critique in this chapter-well, he comes back to that on March $28^{\text {th }}$, but he refers to that specific danger around page 228 of the English translation of his lectures when he talks about eugenics, the problem of eugenics. And he says, "as soon as a society poses itself the problem of the improvement of its human capital in general," that is, once we have a theory of human capital, and once we view the important issue as being improvement of human capital, that "it is inevitable that the problem of control, screening, and improvement of the human capital of individuals ... [is] called for." ${ }^{14}$

Now that could be a sharp critique, actually. It would be a very sharp critique. To a certain extent, it would be a too-sharp critique, I think-which is what Foucault then says. And this picks up on

\footnotetext{
12 Michael Behrent, “Liberalism without Humanism: Michel Foucault and the Free-Market Creed, 1976-1979." Modern Intellectual History 6(3):539-568 (2009).

13 Colin Gordon, “Governmental Rationality: An Introduction," 1-51, in The Foucault Effect: Studies in Governmentality, Graham Burchell, Colin Gordon, and Peter Miller, eds. (University of Chicago Press 1991), at p. 43.

${ }^{14}$ Foucault, Birth of Biopolitics, at p. 228.
} 
this notion of power without coercion, but I think it's a little bit sharper in its ultimate implications. Because on the next couple of pages, on page 230 of the lectures, Foucault then says, "What, you will ask, is the interest of all these analyses?"15 So essentially he's pulling back and saying, "Why do we care about this theory of human capital?" And he says, "You will be aware of the immediate political connotations and there is no need to stress them further." ${ }^{16}$ The immediate political connotations being the ones that we just went over, which was this notion of eugenics. If you have a theory of human capital, it could feed into a very conspiratorial, instrumental vision of how we need to shape human capital. And he says "No, but that's not what I want to do here." "If there were only this lateral political product," he says, "we could no doubt brush this kind of analysis aside with a gesture, or at any rate purely and simply denounce it." Because of course, we can simply denounce eugenics today. "But I think this would be both mistaken and dangerous." ${ }^{17}$

And it's in the final two pages of lecture nine, on pages 232 and 233, that Foucault gives his sharpest critique of the idea of human capital: It is the idea that the notion of investing in human capital creates distinctions and discriminations as to which parts of the population you invest in, and which parts of the population you don't invest in. This is where he writes, on the top of 232, "Only a fine analysis of the composition of the human capital, of the way this human capital has been augmented, of the sectors in which it has been augmented, and of the elements which have been introduced as investment in this human capital, can account for the real growth of these countries. ${ }^{18} \mathrm{He}^{\prime} \mathrm{s}$ responding here to Schumpeter and Weber as to what it is that produces, essentially, wealth-I mean, building on political economy in general, the wealth of nations. And he's saying, it's not just land, it's not just capital, it's not just labor. What you [Becker] put on the table was human capital. And once you've got that on the table, we then make policy, growth policy, based on which populations we should be investing in and which we should not be investing in. And so the sharpest critique is at the top of the next paragraph, where he says: "On the basis of this theoretical and historical analysis we can thus pick out the principles of a policy of growth which will no longer be simply indexed to the problem of the material investment of physical capital, on the one hand, and of the number of workers, [on the other], but a policy of growth focused precisely on one of the things that the West can modify most easily, and that is the form of investment in human capital." ${ }^{19}$

So that kind of sharpens the critique a bit, I think, because although it has at its heart the intervention of "power without coercion," it's not a conspiratorial story about how human capital can lead to eugenics. It's a story about the way in which once we have all bought into-and here's the question of subjectivity-once we all have bought into the notion of human capital, once it is part of our collective imagination, it then produces these policies of growth that involve investing in some populations and not in others. There are populations that are not worth investing in. And so I think that that is what would tie-now again, the book was never written-to a potential critique of our current

\footnotetext{
15 Id. at p. 230.

${ }^{16} / d$.

${ }^{17}$ Id. at p. 230-231.

${ }^{18} / d$. at p. 232.

${ }^{19}$ Id.
} 
condition in the United States; of mass incarceration for example which represents a particular disinvestment in a certain population, particularly young African-American men from the ghetto who are incarcerated. It is a disinvestment in the sense that we have completely disinvested from educational programs, from rehabilitative programs, from all forms of human capital investment. And at the same time, it represents an investment in other populations, for instance the population of the class of guard labor in a particular county. Guard labor serves a welfare function and represents an investment in human capital. You can see this through mass incarceration which would be one example; public housing and the demolition, or current state, of public housing in a city like Chicago could be another example of investing in certain human capital and not in others.

I think that is where you get what Foucault refers to at the end of that chapter and on page 233 as the "seriousness, the[] density, or, if you like, the[] coefficient of threat [of] the very effectiveness of the analysis." ${ }^{20}$ The "coefficient of threat" is clearly a critical term, and what it would amount to is operationalizing the notion of discrimination of investment in human capital-investing in some, and not in others-which is, then, a notion of power without coercion because we've all bought into this. And so it carries the notion of subjectivity which is so dominant in the later part of Foucault's work in the 1980s. That would be, possibly, one reading that-again, somewhat speculative in the sense that it's an interpretation and we don't have the final manuscript-but something that I think would be different than, possibly, an "apology." Okay. So that's four and five.

Gary Becker: Thank you very much. I must say, it's a great pleasure for me to be here. And I must apologize that I haven't read much of Foucault. So it's my limitation. I had heard in the past that he had written some things about human capital and some of my work, but I never read them, Bernard, until you brought them to my attention.

I was very happy to read these two lectures, which impressed me in a number of directions. They are very clear, I thought. He had a good understanding of what human capital consisted of. I didn't find a clear criticism there of human capital. I'll come back to some of the comments you have made.

So where does it stand, in terms of Foucault's attitude toward human capital or towards my work? I mean, it's not just my work - a lot of other people have worked on human capital. Let me make the following comments. And I didn't prepare anything. I felt I'd respond to what was said. So I'm going to be a bit disorganized in my comments as I try to put together some of my reactions to the very interesting points that were made today.

I was happy to see Foucault taking economics so seriously for a philosopher looking at neoliberalism. When I started reading it, I said, well, from what little I knew about Foucault (and not a lot), I assumed he was going to be very opposed to a lot of this material. And it turned out, at least in these two lectures-so my knowledge is a bit confined-but I've listened to what you've said professor [Ewald], and you [Harcourt], and I don't find a change in that. He may dislike certain forms of neoliberalism, but he seemed to take seriously the so-called neoliberalism that was based upon human

${ }^{20}$ Id. at p. 233. 
capital analysis, and a particular approach to understanding how individuals behave, both in the marketplace and in consumption. At one point he says, "Becker has a very interesting theory of consumption. I don't have time to go into that here. ${ }^{\prime 21}$ I think it is a pretty interesting theory. [Laughter]. But it is interesting that he read some of that and made that comment. So it's a theory about how individuals behave under various circumstances, and quite clearly there were power relationships involved in these circumstances, and power of different types-power of the law, etc.

In chapter ten, Foucault goes a lot into crime and punishment. Again, he has a very good discussion of what the theory of crime-modern economic theory of crime and punishment-has to say. I didn't have much to disagree with him. I think he was accurate on what it has to say. He goes also into a theory of formation of laws, which I had a lot of sympathy with as well.

So, where can we read some differences? Surely he was not a pupil of Gary Becker. I mean, I think that would be absurd to believe he was a pupil of me. Take one of the points that you mentioned, Bernard, that one can take the theory of human capital and misuse it, because then you have to allocate your investments among individuals. This is true. It's true at both the individual level and at the level of public policy. But I think whatever theory you approach economic development with, you have to make some judgments of that type. How much you want to invest in capital? Do you want to ignore people? Human capital says you can't ignore people.

What I like to say is: Human capital puts people at the center of an economy. Traditional economics put machinery, physical capital, and land, and, somehow, some undistinguished labor (and Foucault mentions that) at the center. But human capital says: “No. Yes, land-well, land isn't so important in modern economies-but physical capital is clearly important, but the really important form of capital is people. It's people. And not simply what they are born with, but what they, or the government, or the parents do to them-what we call, 'invest in them.'" To me, that's something that anybody who believes that people are the center of what we should be thinking about when we think about economies, when we think about development, that's a liberating point of view. People are the center of the economy. So instead of thinking about, well, take Malthusian population theory-we just have a bunch of people out there, and we're growing, and we have all the Malthusian negative policies, we want to cut down [growth], we want to have poor laws, and so on-all that's thrown out by the human capital analysis. And it says: "No. People are important." They're not just homogenous masses of a number of people; and public policy makes a number of different investments in people.

Now, yes, you have to make choices, but some of these choices, I think, most people and Foucault would like. For example, one of the basic implications of the theory of the investment in human capital is that there is under-investment in people coming from poorer backgrounds. I've stressed that a lot in my work and other people have stressed it: an under-investment in those people. Not that we should forget about them, or put them in prison-incidentally, a lot of them are going to prison for drug laws which, as a liberal, I'm very much opposed to. If we got rid of the drug laws, we'd

${ }^{21}$ See id. at p. 226 ("And I will not talk about it here, because it would take too long, but in Gary Becker there is a very interesting theory of consumption...") 
get rid of a lot of the imprisonment, particularly of minorities. To me it's very counter to a neoliberal point of view, or what I call-I don't use the word "neoliberal" - a classical liberal [point of view]. What we like to say, to the extent I touch on philosophy, is to distinguish between American liberals and classical liberals. And I feel I belong in a classical liberal tradition, and human capital expands on that liberal tradition by saying, yes, it's important who you invest in, but it doesn't mean you're only going to invest in people coming from rich backgrounds.

In fact, where societies-modern societies and traditional societies-have a problem is that people coming from poorer backgrounds are neglected, and they have very little investments in them. If one thinks of this as educational policy, school policy, government policy, individual policies, the problem is how do we get more investment in people who have the talents and so on, but they're at the disadvantage of being born into poor and low educated families, and they're suffering because after a few years they are already behind in the starting point? That's what the human capital analysis would stress.

So, to me-I have no idea whether Foucault would like that implication-but to me that is the implication of human capital analysis. And it goes back a long time. It's in my book published in 1964 on human capital. ${ }^{22}$ It's in a large fraction of all the literature on human capital. That type of issue: How do you overcome the, what we call, under-investment in the human capital of people who are disadvantaged. Now, maybe that's because of power relations. They don't have enough power, and they're neglected in society. I'm perfectly happy to accept that. So we try to create an analysis that fights against that view. That says that neglect of this part of the population is not only inequitable, but also inefficient. Economics is a lot about efficiency. I mean, I don't think economics brings in great new ideas about what equity should be. But economics is a lot about efficiency, and it becomes interesting when you can say something that most people consider inequitable and it is also inefficient, because you can try to correct that and improve on both margins. That's one of the aspects of the neglect of the human capital investment in people from poorer backgrounds. You can invest in them more. That's more equitable, most people would say that's more equitable, but it's also more efficient in a variety of circumstances. So, to economists, that's a great advantage, and I would think to Foucault, I would think to the French philosophers, that would be a tremendous advantage. So, that's one set of reactions.

Let me now make a point that is kind of orthogonal to what both of you have said, but still is relevant. If you think of, in general, the French acceptance of work on human capital and similar work lagged behind that in most of Europe. The French were late, and I'm not talking about the French philosophers in particular and I'm not talking about Foucault in particular, I'm talking about French economists-maybe under the influence of, not Foucault, but some others, it lagged behind. If you look at the spread of human capital, it started in the United States, and for a long time was analyzed just in the United States, and then it began to spread through Great Britain, Germany, other parts of the world, Asia, and so on (the Chinese love the concept of human capital). The French were very late in getting

${ }^{22}$ Gary S. Becker, Human Capital: A Theoretical and Empirical Analysis, with Special Reference to Education (University of Chicago Press 1964). 
into it. It's only until you got a new generation, and here I'm referring to the economists, a new generation of French economists who are coming to power now, that they began to see the importance of human capital. Many of them trained abroad for their doctoral degrees; they began to see the importance of human capital. So I was shocked, I'll just tell you personally, I was shocked in the Fall, well, it started in the Spring, when I received an invitation from a well-known French economist that they wanted to have a big conference celebrating the $30^{\text {th }}$ anniversary of my book on the family-which Foucault would say is a neoliberal approach to the family, which it is, a liberal approach to the family. Why was I shocked? Because the last place I thought it would come from was France. It turned out I was ill at the time, I couldn't attend,, but they had a great conference. And it shows a lot of great work going on, a fair bit in France, so I think that the French economists are catching up in this regard. Now why were the French so slow in getting into this? Was it because there was opposition from others on the philosophy of human capital analysis and the liberal approach-I don't know the answer to that question. But as a fact, I am confident, that is a fact. That is one point I wanted to add, because to my great disappointment I couldn't attend that conference, I wanted to attend. I figured, French economists finally caught up and I can't go there to enjoy it a little bit.

A couple of other comments, and then I think we should have a general discussion. Some people have said in the early literature (and I was happy to see Foucault didn't say this at all), but some critics in the early work on human capital-and there was a lot of criticism in the United States, a lot of criticism by American economists, there was a battle to get human capital concepts accepted among American economists, let alone economists in the rest of the world-and the criticisms that were made at that time was that human capital was demeaning to the human being, that it treated human beings as cattle. Some people said, "Oh, you're talking about human cattle" or "machinery." And Foucault at some point uses the machinery analogy. ${ }^{23}$ In fact, it turns out, I've used that analogy as well, not knowing Foucault had done it. It is treating it like a machine, up to a point.

Up to a point, you treat people like machines. But it's only up to a point. And why? Because one of the basic principles-[turning to a student] you took the course in human capital, so you know-one of the basic distinctions we make in the literature is that we say yes, human capital is capital, but it's a very different form of capital. For example, you take a machine, you don't care if the machine is working in a swamp or not, but people do care whether they're working in swamps or not, because their human capital they have is part of them. So you have to develop the theory of human capital as partly related to the theory of machinery, but in a very major part very different from the theory of machinery. And I didn't see that in Foucault, but I think that's a fact as you look at human capital analysis. It's partly like the theory of machinery, but in major part, the whole purpose-I give a course on human capital every Spring and my first lecture I say, yes, we can use a lot of the tools from general capital theory to apply to

\footnotetext{
${ }^{23}$ See Foucault, The Birth of Biopolitics, at pp. 224-230 ("In other words, the worker's skill really is a machine, but a machine which cannot be separated from the worker himself, which does not exactly mean, as economic, sociological, or psychological criticism said traditionally, that capitalism transforms the worker into a machine and alienates him as a result. We should think of the skill that is united with the worker as, in a way, the side through which the worker is a machine, but a machine understood in the positive sense, since it is a machine that produces an earnings stream." Id. at p. 224).
} 
human capital, but there's a reason why we want to have a separate course on human capital, because a lot of those tools are not really applicable. Some of them are, but some of them are not.

There's a really important distinction between human capital and another capital, such as if I have human capital I have to take my capital wherever I go. If I have a machine, let the machine work wherever it wants. We don't really care, and we don't worry about whether the machine cares about doing it or not. If I invest in my human capital, I cannot in modern societies use my capital as collateral to borrow loans. That's why we have such a poorly developed commercial market for loans and investments. You look at student loans: they've developed extensively in the United States because of the government guarantee and subsidy to student loans. There's very little commercial market in that. And we say, yes, the reason for that is because of the fundamental difference between human capitalif I buy a house, I can give my house as mortgage. If I don't make my payments, they take my house away from me, as we're seeing all these foreclosures going on now. I can't give myself as collateral. Now, in the past with slavery and other forms of indentured servitude you could do that. In modern society we've ruled that out, for good reasons I think. And so you can't do that, and I think it makes it very difficult for poor people who don't have other forms of capital to invest in themselves. So I come back to the issue why we get under-investment in poor people, and it's partly because of the distinction between human capital and other forms of capital.

Apropos of the early views that human capital is demeaning, I think the economists have forgotten about that now. It's no longer brought up very much. And politicians have forgotten about it now. I mean you cannot have a politician in the United States, at least, and I think in many countries, who can get involved in any campaign without mentioning many times the words "human capital." Now, they can use it to justify policies having nothing to do with human capital, but to them it sounds good. You're not giving money to people, you're investing in their human capital-and sometimes that's what you are doing. And sometimes you're just giving people money. [Laughter]. But it's better to say you're investing in human capital than to say you're just giving them money.

I was very interested when Foucault said human capital is like machinery, because that's a good insight. I thought he had a good insight there. On the other hand, if he had written another lecture about this, I'm sure he would have said, "but it's not exactly like machinery." ${ }^{24}$ Because it is not exactly like machinery. And the differences, the differences are really important in understanding the different role of human capital, such as education. What do we mean by human capital? For those of you who don't know anything about it, things like education, investment in health, on-the-job training, migration-all these things are aspects of what we call human capital. So why are those things so different from companies just investing in more machinery or less machinery and inventories and plants and so on? The theory has some things in common, but they're really very different. And in order to understand those differences, I think you really give the individual more importance rather than less importance.

\footnotetext{
${ }^{24}$ Cf. id, at pp. $224-225$.
} 
To come back to my final point-and as I said, I'm speaking at random here because I'm just thinking as I react to points-the link to eugenics. Yes, you can always link any ideas to some perverse use of it. But there's no fundamental link, certainly, in the analysis of human capital. Yes, some people have more, some people have less. You accept that. I think anybody has to accept that. We see that all the time. Some people here are undergraduate students, graduate students, some people quit school and don't finish high school. Everybody knows that. It happens in all countries, certainly happens in the United States. But there's nothing in the theory of human capital, particularly in the liberal-and I am now using the European, the traditional liberal, connotation of liberal-in the liberal view about eugenics. Because the liberal view is that you respect the individual. Individuals are not simply instruments of the state. Even with education. What I generally favor is, you offer them opportunities. As much as possible you try to avoid requiring them to do this or that. Now we do have minimum schooling laws and we do have certain requirements, and I think some of them make some sense, but as much as possible you try to give people opportunities and enable them to take advantage of these opportunities. To me, eugenics has no place in human capital analysis and nobody, to my knowledge, who has been a proponent of human capital analysis has ever adopted anything close to a eugenic point of view. It's generally been the opposite.

So, let me see if I have any other comments. Yes, I do. You said that the man produced by human capital is a fiction. It is. But all theories are fictions. I'm not going to literally describe all actions in any theory, I don't care if it's physics, biology, economics, any social science, any physical science, any biological-they're fictions. So you're taking certain aspects of behavior and you're saying, "can I take these aspects of behavior - a very simple model of humankind, men and women - can I take that simple model and understand a lot of things about the world and then help to prescribe things for the world?" Yes, it's a fiction-I'm proud of that! It should be a fiction. If I read more Foucault, I'm sure I would find a lot of fictions in Foucault. But, I wouldn't call that a criticism. You have to do that to analyze in an insightful way about the world. If you want to just describe, in some literal sense, everybody's going to be different. Every one of us here is going to be different. And yet, in some dimensions, we're the same. So maybe we abstract from these differences for a lot of problems and just look at the similarities. That's what theory does. Theory is an abstraction, it's a fiction. And the question is - when analyzing good and bad theories-which fiction works better for whatever problem you have in mind. If it's analysis, it's prescribing behavior, which fiction works better?

I think human capital has been a great fiction. It's not been an unchanging fiction, the fiction has changed over time, but it's been a great fiction. I'm proud of it. [Laughter]. But yes, it is a fiction. Nobody would deny it's a fiction. But you have to say, is it a useful fiction? And maybe, 20 years from now, we'll have a different fiction that will be better. But at the moment, this is a very useful fiction for a lot of problems. I'll stop here and see where we are.

Bernard Harcourt: François, I know you wanted to jump in.

François Ewald: Yes, I will perhaps change my role a little. I am going to address and impress upon you another kind of critique, I think, which is present in the text. So, Bernard used what is, for me, 
interesting in the page he quoted-the passage where Foucault doesn't retain that critique regarding eugenics. ${ }^{25}$ He says, that is not important at this time. And you have to read the last footnote of this chapter, where there is a mention of Bourdieu. ${ }^{26}$ What I think for you-

Gary Becker: What chapter?

Bernard Harcourt: So there was in the manuscript-he didn't get to the end of his lecture...

Gary Becker: Are we talking about chapter ten?

Bernard Harcourt: Chapter nine. And so this is basically a reproduction of what the manuscript said.

François Ewald: But he quotes Bourdieu in what I think in a very interesting manner for you, because between Gary Becker and Pierre Bourdieu, manifestly at this time, Foucault chose Gary Becker...

Gary Becker: He had good taste. [Laughter].

François Ewald: ... and he gives a reason about the French position in respect to your idea of human capital, which is precisely the doctrine of Bourdieu. And he makes, that is interesting...

Gary Becker: I wondered when I read that whether there was any intellectual rivalry between the two, and that's why he was... Was there any intellectual rivalry between Bourdieu and Foucault?

François Ewald: Any intellectual...?

Gary Becker: Rivalry.

François Ewald: Naturally. [Laughter]. Yes. That is not specific. At this time Bourdieu was seeking to enter the Collège du France...

Gary Becker: So my inference was a little bit right.

\footnotetext{
${ }^{25}$ Foucault, The Birth of Biopolitics, at pp. 230-233.

${ }^{26}$ The passage in question, from the manuscript of Foucault's lecture, reads:

"Problematizing in a different way all the domains of education, culture, and training that sociology has taken up. Not that sociology has neglected the economic aspect of this, but, confining oneself to Bourdieu,

- reproduction of relations of production

- culture as social solidification of economic differences

Whereas in the neo-liberal analysis, all these elements are directly integrated in the economy and its growth in the form of a formation of productive capital.

All the problems of [inheritance?]-transmission-education-training -inequality of level, treated from a single point of view as homogenizable elements, themselves in their [turn?] refocused no longer around an anthropology or an ethics or a politics of labor, but around an economics of capital. And the individual considered as an enterprise, i.e., as an investment/investor (...).

His conditions of life are the income of a capital." Id., at p. 233 n*.
} 
Bernard Harcourt: Although, it's not entirely clear from the words in the manuscript that it's a placing of Gary Becker on one side-I think it's a differentiation of what's been done in French sociology versus...

François Ewald: But Bernard, if I can, I will use a joker, because I was close to Foucault at this time and I know what his position was regarding Bourdieu! [Laughter]. But that is not fair. [Laughter]. But I think you can find in the lecture another critique that is, I think for me, much more important. And it is about the consequence of your vision, of your objectification of man, about the behaviorism. And for me, this may be a question. Maybe I am wrong. This may be a good opportunity to correct me. I am afraid that this theory-I am missing the words and will try another way.

From an economic perspective, the vision of man becomes very, very poor. Man is a being who responds to stimuli from the environment, and we can modify his behavior with a choice of stimuli. And what government is, what power is, is the use of different kinds of stimuli. The economic theory gives a set of tools, a "good manner" to use stimuli to obtain the right comportment. In this respect, the result of the theory, perhaps, is to produce a vision of man that is very impoverished. We start with the theory of the agent and we can understand how people make decisions in certain contexts, with certain information, and so on. But at the end, we have a poor behaviorism, and the resulting vision of man from this behaviorist perspective is not very interesting. For me, you can find this critique, but not developed by Foucault. I think it means that the danger of this perspective-of your theory of microeconomics - the danger will be to allow a theory of power and a practice of power, a very poor practice of power that is, as a result, very impoverished. I think that is another critique.

Bernard Harcourt: Now, in what sense is that different than the question of the demeaning character of human capital? Gary had talked about that other critique, you know, "human cattle," the demeaning idea of human capital that some people impose as a reading on Foucault-although I don't see it there. But this is different, I take it, than just "it is demeaning to humankind." Right? Your critique?

François Ewald: Yes. My critique is that the resulting conception of governmentality is not rich. It is not sufficiently rich that we should wait and give way or open the possibility for a practice of government, of governmentality, that, in the long-term, may not be efficient. And I don't want to make a false accusation, but if you see how the people, for example in the financial sector, behave now, you can see that they are used only in respect of their competences and not with the idea of their own responsibility. The debate after the financial crisis of 2008 was whether there was an error by the regulators; and this is because we view them, essentially, like dogs in a Pavlovian theory: we have interests, we have desires, and it is the job of the regulator to produce good regulations, the right incentives, good incentivization, so that we can make or choose the right decisions. I think perhaps, and this is maybe my moral vision, that we can ask people to see themselves in another manner than like dogs in a Pavlov experiment.

Gary Becker: Let me respond to that. I see human capital as really doing just the opposite, if I can be blunt: as freeing up individuals. I mean if I look at a traditional theory of economics, yes, there's 
something of that. People have what we call preferences, they respond and get some results. What the theory of human capital says is that people-it's part of the theory of human development-people can develop themselves in various ways. They are not simply programmed to go down, in a particular way, and then you have laws that just sort of kind of manipulate them and push them around. They can develop themselves in various ways. Of course, how they want to develop themselves will be a function of the environment they're in, the governmental and other environments, what other people are doing. So they can develop themselves.

Instead of saying that the vision of man is poor, I would say the vision of man is rich in this approach, because you enrich both what people do as consumers - that's why I think Foucault says this was an interesting theory of consumption-and you enrich what they do in terms of a lot of their other life decisions that would go beyond consumption, in terms of their education, how they might invest to respond to different government laws, how they might evade bad laws. I mean, yes, if you have things under certainty, there's a certain deterministic aspect of behavior you can modify a lot. But within that broad spectrum, people have a variety of choices they can take. It wasn't part of the so-called economic man before the theory of human capital was developed. That broadened the choices available to people, not narrowed them. So people can do all kinds of things now and, while traditionally if you were to say you were criticizing, or Foucault was criticizing, a traditional view of economic man-they're selfish, and they have certain particular preferences, ideas and they just do it, they don't care about anything else-yes, that's a caricature. That's a fiction, but a bad fiction in my judgment. The movement pushed by the human capital point of view, is to say that's a bad fiction. People are much more complicated than that. They have concerns about other people, not only in the family and outside the family, and they can take actions to improve themselves. They're in different dimensions, so to me it's an uplifting point of view, rather than a limiting point of view.

How it links to power relations... well, I mean, you'd have to compare it with other theories of how people behave. I mean, I think of this maybe as a pragmatist. I'm thinking about behavior. I look at France, and I say how can I understand what young French people are doing? In an environment where there's a lot of unemployment for the low-skilled and so on, how can I understand that? Or if I look at the United States, how can I understand what young African-American men are doing? To me, this theory-and I'm not saying I fully understand what they're doing-but the theory says, well, they have a lot of different options available.

What we're pointing out to them is, if you drop out of high school in the United States, you're pretty much destined to be unemployed, to have low earnings, to be in poor health, to have low marriage rates, and the like. That's what the theory points out to them. And what it then points out to them is that you can overcome that in various ways. Not you alone, but with the state and so on. So to me it's a very much uplifting theory, where again, we're putting the individual-what they do-at the center, rather than as the instruments of what others are doing. They're the center. And it's their interaction with each other and with the power relationships that give us the outcomes. So I find it very difficult to agree with the notion that it's a demeaning view of the individual. So we'll stop there, I guess, we're running out of time. 
Bernard Harcourt: Alright, excellent. So what's happening now is that someone else needs this seminar room, so we were able to squeeze into Foster 505, but now I think we are "occupying." ... I want to thank Professor François Ewald and Professor Gary Becker.

Readers with comments may address them to:

Professor Bernard Harcourt University of Chicago Law School

1111 East 60th Street

Chicago, IL 60637

harcourt@uchicago.edu 


\section{The University of Chicago Law School Public Law and Legal Theory Working Paper Series}

For a listing of papers 1-375 please go to http://www.law.uchicago.edu/publications/papers/publiclaw.

376. Bernard E.Harcourt, On the American Paradox of Laissez Faire and Mass Incarceration, March, 2012

377. Bernard E. Harcourt, The Politics of Incivility, March 2012

378. Bernard E. Harcourt, Fantasies and Illusions: On Liberty, Order, and Free Markets, March 2012

379. Saul Levmore and Ariel Porat, Asymmetries and Incentives in Evidence Production, March 2012

380. Aziz Huq, Forum Choice for Terrorism Suspects, March 2012

381. Lee Anne Fennell, Picturing Takings, April 2012

382. Eric A. Posner and E. Glen Weyl, An FDA for Financial Innovation: Applying the Insurable Interest Doctrine to 21st Century Financial Markets, April 2012

383. David Fagundes and Jonathan S. Masur, Costly Intellectual Property, April 2012

384. Rosalind Dixon and Martha C. Nussbaum, Children's Rights and a Capabilities Approach: The Question of Special Priority, May 2012

385. Laura M. Weinrib, The Sex Side of Civil Liberties: United States v. Dennett and the Changing Face of Free Speech, May 2012

386. Bernard E. Harcourt, Punitive Preventive Justice: A Critique, May 2012

387. Saul Levmore, Harmonization, Preferences, and the Calculus of Concent in Commercial and Other Law, June 2012

388. Tom Ginsburg, Courts and New Democracies: Recent Works, June 2012

389. Rosalind Dixon and Tom Ginsburg, Deciding Not to Decide: Deferral in Constitutional Design, June 2012

390. Daniel Abebe, The Global Determinants of U.S. Foreign Affairs Law, July 2012

391. Daniel Abebe, Rethinking the Costs of International Delegations, July 2012

392. Eric A. Posner and David Weisbach, International Paretianism: A Defense, July 2012

393. Aziz Z. Huq, When Was Judicial Self-Restraint, July 2012

394. Aziz Z. Huq, The Institution Matching Canon, July 2012

395. Eric A. Posner, The Institutional Structure of Immigration Law, July 2012

396. Eric A. Posner and Alan O. Sykes, International Law and the Limits of Macroeconomic Cooperation, July 2012

397. M. Todd Henderson and Frederick Tung, Reverse Regulatory Arbitrage: An Auction Approach to Regulatory Assignments, August 2012

398. Brian Leiter, Waldron on the Regulation of Hate Speech, July 2012

399. Aziz Z. Huq, Structural Constitutionalism as Counterterrorism, August 2012

400. Aziz Z. Huq, Binding the Executive (by Law or by Politics), August 2012

401. Gary Becker, François Ewald, and Bernard Harcourt, "Becker on Ewald on Foucault on Becker" American Neoliberalism and Michel Foucauilt's 1979 Birth of Biopolitics Lectures, September 2012 